\title{
Pricing as a marketing mix element: Investigating its effect on market share for supermarkets in the Ngaka Modiri Molema district of the North West province of South Africa
}

\author{
Ateba Benedict Belobo, Hein Johannes Prinsloo \\ School of Management Sciences, North-West University, Mafikeng Campus, South Africa \\ Email address: \\ atebabenedict@yahoo.com (A. B. Belobo), Hein.Prinsloo@nwu.ac.za (H. J. Prinsloo)
}

\section{To cite this article:}

Ateba Benedict Belobo, Hein Johannes Prinsloo. Pricing as a Marketing Mix Element: Investigating its Effect on Market Share for Supermarkets in the Ngaka Modiri Molema District of the North West Province of South Africa. International Journal of Business and Economics Research. Vol. 3, No. 6, 2014, pp. 196-210. doi: 10.11648/j.ijber.20140306.11

\begin{abstract}
This paper propped up as a result of the lack of awareness on the role of pricing in market share gain or loss among retailers in general. The empirical focus of the study was at the Ngaka Modiri Molema district in the North-West province of South Africa. The researcher saw that the identified problem negatively affected the profits of retailers in the Ngaka Modiri Molema district. Thus, there was need to carry out this study in order to improve the awareness level of the role pricing has in market share gain or loss among Ngaka Modiri Molema retailers. It was also aimed at developing a pricing decision support system that can assist Ngaka Modiri Molema retailers in pricing decision making. The study was performed on 11 selected items commonly available in the database from the three largest supermarkets in the fast consumer goods retail sector at the Ngaka Modiri Molema district (Pick n Pay, Spar and Shoprite supermarkets). A panel data technique was used in determining the outcomes of this paper. The study revealed that pricing play a major role in market share gain or loss among Ngaka Modiri Molema retailers. Hence, there is need to increase retailers awareness with regards to the mentioned finding. Practical recommendations were made and a pricing decision support system was developed to assist Ngaka Modiri Molema retailers.
\end{abstract}

Keywords: Marketing Mix, Pricing, Market Share, Fast Consumer Goods, Retailing

\section{Introduction}

Rapsomanikis and Sarris (2009-2010) said that the world has currently experience a dramatic increase in the prices of commodities like maize, rice and wheat. Although the prices of such commodities have now declined, they continue to remain at a significantly high rate compare to the prices pre 2005. Rapsomanikis and Sarris alluded that in general, the changes in commodity prices are characterised by the increase or decrease in purchase. This is because these fluctuations in prices present a serious challenge to consumers buying power.

Balcombe (2009-2010) indicated that changes in price, either increase or decrease, impact on the trading position of retailers in a long-term. Whitehouse and Associates (2007:35) maintain that the Bureau of Marketing Research predicted a slower average growth in the South African fast moving consumer goods market from 2007 due to the economic recession, which generated an indirect decline in consumers' income. Claessen et al. (2009) mentioned that an economic recession like the one during 2008, can affect consumers' consumption by more than one percent after every quarter in any economy. Roger (2003:1-2) said in such situation is key that retailers adopt their marketing mix strategy to changing consumer behaviour tendencies. Munusamy and Hoo (2008) have carried out a study in Malaysia to determine which marketing mix element was the most appropriate for the fast consumer goods retailer Tesco (a supermarket). In their study, results revealed that pricing had the largest impact on Tesco performance compared to any other marketing mix elements. As indicated by Lee and Griffith (2004), adjustment of prices to market conditions has a positive influence on the market share and adaptation of the pricing strategy could increase the market share of a business. This paper seeks to unpack the relationship between pricing strategies and market share of fast consumer goods retailers, provide applicable recommendations and a pricing decision support system for 
Nkaga Modiri Molema district.

\section{Literature Review}

In this section, a brief empirical literature relating to the role of pricing in market share gain in South Africa and the Ngaka Modiri Molema district will be briefly discussed. The role of price in the market and its role as an important tool for market share gain will conclude this section. Marketing mix is the set of controllable marketing tools consisting of product, price, place and promotion (Shankar \& Chin 2011:1542).

\subsection{Marketing Mix Effectiveness in the North-West Retail Sector}

Information supplied by Managers of the chosen supermarkets in this study (Shoprite, Pick n Pay and Spar), indicated that centralisation is a primary factor affecting their performance. Thus, one can say the high level of centralisation practised by these supermarkets is a clear indication of limited application of the marketing mix elements. Guruprakash and Sohn (2008:9) mentioned that centralisation impede the ability of departmental stores to appropriately respond to customer needs and improve customer service due to limited powers in decision making. De Jager (2004:112-113) performed a study using the Living Standard Model (LSM) to determine target consumers for Pick $\mathrm{n}$ Pay and Shoprite in (North-west province, Potchefstroom) Results obtained include:

Current market segment targeted by these retailers differ from their actual target market.

The marketing mix elements that were in place were not in any way appropriate to what was seen to be the actual market of these retailers.

De Jager's findings indicate a clear misapplication of the marketing mix. He further assumed that an inappropriate marketing mix to wrong target markets is likely to also be the case among supermarkets in other NW province areas. Furrier et al. (2007) has stressed that marketing activities has a great impact on the performance of a business in the market place or to achieve its market share. A large number of supermarket retailers in the Ngaka Modiri Molema district can be viewed to be offering poor business services thus, a possible misapplication of the marketing mix elements. As confirm by Southern African Legal Information Institute (2012) database, there were 14 court cases in 2012 concerning poor customer service with regard to the retail sector at the Ngaka Modiri Molema magistrate court in Mafikeng. However, it was earlier mentioned that Munusamy and Hoo (2008) confirmed that pricing play a major role in market share gain among all other marketing mix elements.

\subsection{Pricing in the Market}

Reviere (2009:1) pointed out that the price concept differs whether a person lives in a market economy, planned, command or traditional economy. Because pricing influence the economic actions in a market economy, it is best to discuss pricing concept on a market economy basis. Palley (2004:1-2) alluded that in a market economy, the contemporary framework of neoliberalism emphasises the efficiency of market competition, which is based on the microeconomic theory of pricing, the key variable influencing the demand and supply in the market place. Pitner (2007:1) indicated that when understanding price in the market or how it works in business, all is about the demand and supply functions. Pitner, further indicated that from supply perspective, the higher the price of a product, the higher the supply, the lower the price of a product, the lower the supply. The demand perspective is connected to consumer behaviour in that if pricing affects consumers' buying behaviour negatively, the demand curve will slope downward, meaning a drop in purchase behaviour. Alternatively, if pricing is positive, consumer buying power will increase, leading to the demand curve sloping upward, more sales and market performance for the business.

Moutinho and Chien (2008:162) indicated that even though in recent decades other factors are also now playing a role in influencing consumer behaviour or decision to make a purchase, price still remains the most important element determining a business sales, profitability and market share. Wiid (2012:6) said consumers will always attach a certain value for the product they want to buy and these values is always reflected in the price of the product. The influence of price on sales and its consequent effect on market share can be analyse on the consumer buying decision model. Plessis and Rousseau (2007:260) refer to consumer decision model as the primary decisions consumers make whether to purchase or not, to spend or save their money when engaged in a particular buying situation.

Egan (2007:54) specify that the decision to make a purchase involved the following stages: problem recognition, information search, evaluation, decision, purchase and postpurchase evaluation. A consumer decision to purchase a product with regards to price may be based on; available income with regard to the offered price of a product, information on different price offers from competitors, evaluating the best price offer, purchasing from the retailer with the best price and if the is value for the price paid. Plessis and Rousseau (2007:269) said, repeat purchase of a product or service will depend on the post purchased experience by the consumer. If for example a consumer could experience a better value for the price paid, it may lead to repeat purchase of the product or service. Conferring to Khan (2011:43) consumer decision model is a good determinant to identify cause and effect relation in the market. From the above discussed influence that price has in the market, this study focuses on showing that price is an important tool for Ngaka Modiri retailers in gaining market share.

\subsection{Pricing Decision Making}

Indounas and Avlonitis (2009) indicated that pricing is an important management tool to achieve the objectives of the organisation. Pellinen (2003:218) also mentioned that pricing 
is one of the most important or central management tasks for any business. According to Dutta et al (2003) businesses without efficient pricing process may be unable to set prices that reflect the wishes of its target customers. Blyth (2006:448) and Escalana et al. (2012:159) indicate that pricing process involve all the steps in determining final price for products or services. Conferring to Hinterhuber and Liozu (2012) implementing a pricing structure requires a high degree of discipline from any business, and any business can improve its pricing performance so far as its pricing approaches are well-structured. Pricing process is represented in figure 2.1 .

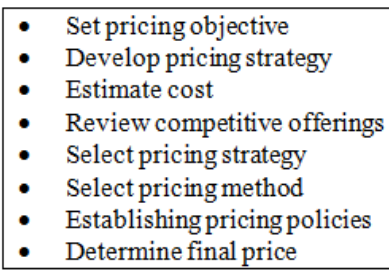

Figure 2.1. Pricing process Blyth (2006:448)

\subsection{Market Share Scramble among South Africa Supermarket Brands}

According to Venter \& Van Rensburg (2011:118) a market share indicates how an organisation is performing relative to its competitors and a market share is calculated by dividing an organisation's share by the total sales of all organisations for a specified product-market (Venter \& Van Rensburg, 2011:118). The market share of any business is considered to be the key element of the business performance. Ernst and Young (2004:39) indicate that the most pressing issue in the South African retail sector is currently the battle for market share. This is due to the rapid growth in the retail sector consequent with relative maturity. Retailers are highly competing against each other to achieve a positive market share position. McGregor (2013) indicated that there has

been a public battle in the media between Shoprite and Pick $\mathrm{n}$ Pay over who has the dominant market share. This indicates how important it is for retailers of fast consumer goods to be market share dominant. Derby (2013) mentioned that South Africa's oldest and most enduring retailer, Pick n Pay, has lost a great deal of its market share to rivals like Spar and Shoprite since 2012. Derby highlighted that Pick n Pay is still struggling to regain its lost position for two successive years.

Supermarket brands scrambling for market share is also the case in the North-West province. Dirkie (2011/2012:15) indicated how supermarket retailers like Choppies Limited (ltd) are performing relatively well. This has made Choppies a faster growing retailer in the Northwest province as compare to its competitors in terms of market share since its introduction in 2008 into the province. Keeping satisfying consumers loyal is a common tactic to increase sales and market share since supermarkets are often located within close proximity and sell more or less the same products. Thus, each retailer's ability to sell its merchandise sustainably largely depends on the strength of its marketing mix activities especially pricing (Marriri \& Chipunza, 2009). Euromonitor International (2012) indicated that in South Africa supermarket retailers like Shoprite and Spar Group have increased their market share over competitors, due to their ability to implement pricing strategies that will provide commodities to consumers at reasonable prices. Scheer (2010) indicated that in South Africa consumer increase knowledge and expertise of industry and store prices, has led to repeat purchase or loyalty to certain store brands. This is because consumers are always interested on better offers by competitors.

\section{Research Methodology}

Table 3.1. Summary of data description

\begin{tabular}{llll}
\hline \multicolumn{2}{l}{ Dependent variables (sales of selected 11 items) } & \multicolumn{2}{l}{ Independent variables (prices for the 11 selected items) } \\
\hline Items & Code for items & Items & Code for items \\
\hline White star maize meal 5 kg & Q1 & White star 5 kg & P1 \\
Tastic rice 2kg & Q2 & Tastic rice 2kg & P2 \\
Coke 2 litters & Q3 & Coke 2 litters & P3 \\
Lays potato chips 125g & Q4 & Lays potato chips 125g & P4 \\
Axe deodorant spray100ml & Q5 & Axe deodorant spray100ml & P5 \\
Sasko bread 700g & Q6 & Sasko bread 700g & P6 \\
Chicken braai cuts 2kg & Q7 & Chicken braai cut 2kg & P7 \\
Golden apple 1kg & Q8 & Golden apple 1kg & P8 \\
Nutriday yogurt 6x100ml & Q9 & Nutriday yogurt & P9 \\
Colgate tooth paste100ml & Q10 & Colgate tooth paste100ml & P10 \\
Styvensen cigarette (pack) & Q11 & Styvensen cigarette (pack) & P11 \\
\hline
\end{tabular}

The research design used in this study was based on a quantitative research method approach. This approach was used because, the occurrences of behaviour were counted, correct answers or errors were also counted and all recorded in quantity. Within this design the parameters of an exploratory strategy was used. An exploratory research strategy was considered due to limited research done on the identified problem within the specified sample geographical area. This paper's empirical focus was on Ditsobotla, Mafikeng and Romotshere Moila municipalities. According 
to Stat SA (2009) these focus municipalities represent $80 \%$ of the total Ngaka Modiri Molema District. The three indicated municipalities were targeted since the researcher aimed on selecting only supermarket stores with a large client base, which is reflected in the focus municipalities. All selected supermarkets for this study experienced a sales turnover above 15,000 product units (regardless of brand or trademark) and client base above 10, 000 monthly.

The paper made used of purposive sampling, which was employed in order to enable the researcher to select supermarkets with qualified reliable and applicable information. The largest supermarket store from each sampled supermarket brand (Pick n Pay, Spar and Shoprite) was selected as participants. This three supermarket brands together represent more than $80 \%$ of retail market share in the Ngaka Modiri Molema district. Participating employees included the regional marketing manager and branch the point of sales application of the three participating super market stores database. Data was on a monthly basis from January 2011 to August 2013. The variables from the data collected included Selling Price Index (SPI) and the turnover rate (sales) for 11 selected items commonly available in the database of the selected supermarkets (Shoprite, Pick n Pay and Spar). The SPI was used to monitor the continuous change in the pricing of items in supermarkets and also monitor the impact of these price changes on consumer purchase tendencies. The monthly sales figures for selected items were used as estimation for market share for each supermarket. Thus the dependent variable was price and the independent variable was market share. A summary of data description based on the 11 selected are represented in table 3.1

The analytical technique used in this paper was based on three largest fast consumer goods retailers in the Ngaka Modiri Molema district to establish the relationship between their pricing and its effect on market share gain or lost. A panel data refer to pooling of observations on a cross-section of households, countries or business organisations and following them over several time periods (Baltagi, 2008:1). A panel data analyses was best suited for this study because it takes an organisations' specific heterogeneity in to consideration. The second reason was that, due to the repeated cross section of observations, panel data are better suited in studying the dynamics of change. Lastly panel data among "organisation's". It was thus, clear that the researcher could effectively achieve the objective of the study by employing a panel data analyses. This objective was to

Table 4.1a. Panel data unit root tests for price data manager of each supermarket brand. Data was collected from the panel data analyses. The researcher used a panel of the analyses are very effective in evaluating strategies or policies

investigate the degree to which constant changes in pricing decisions by the three largest fast consumer goods retailers' in the Ngaka Modiri Molema district impact on their market share gain or share lost. In order to run the linear regression, four panel data tests were run. These tests involve the panel unit root tests, poolability, model estimation tests and the diagnostic tests. After performing this panel data tests, results from model estimation were forecasted to predict the future.

\subsection{Model Specification}

The Panel Ordinary Least Square (POLS) model was used in running regressions. The model specification (relationship between the dependent - market share, and the independent variable - pricing) of this paper was then equated as $M S V_{i t}=\beta_{0}+\beta_{1} P_{i t}+\varepsilon_{i t}$ Formula (3.1). From formula (3.1) indications represented are as follows:

Market Share Value $(\mathrm{MSV})=$ the dependent variable that the model is trying to predict

$\beta_{O}=$ the intercept of the equation.

$\beta_{1}=$ the slope coefficient of the price variable.

Price $(\mathrm{P})=$ the independent variable that was used to predict the dependent variable.

$\varepsilon=$ the error term or the regression residual variable. It represented all other variables like (quality and advertising) that could have an effect on the market share other than the independent variable $(\mathrm{P})$.

$\mathrm{i}=$ all the cross section (supermarkets) who participated in the study.

$\mathrm{t}=$ the time period under study (January 2011 to August 2013).

This studies objective was to determine relationships between dependent and the independent variables. Based on this, POLS seem best suited in determining the mentioned relationships.

\section{Results and Discussion}

The following section will present and discuss findings from the empirical research. The authors want to highlight that the three sampled supermarket brands represent more than $80 \%$ of the market shares in the fast consumer goods retail sector in Ngaka Modiri Molema district. Thus, the three supermarkets were a faire representation of the entire fast consumer goods retail sector in the Ngaka Modiri Molema district. Three panel data unit root tests were performed separately for each data category (sales data and price data). All the performed unit tests produced a stationary outcome in all levels. Unit root results are presented in table $4.1 \mathrm{a}$ and $4.1 \mathrm{~b}$

Table.4.1b. Panel data unit root tests for sales data

\begin{tabular}{lllll}
\hline Results for price data & & \multicolumn{3}{l}{ Results for sales data } \\
\hline Test & Coefficients & pvalue & Test & Coefficients \\
\hline Levin, lin,Chu & -2.171 & $0.015^{* *}$ & Levin, lin,Chu & -3.101 \\
Im, Pesaran\& Shin & -5.468 & $0.000^{* * *}$ & Im, Pesaran\& Shin & $0.001 * * *$ \\
ADF-Fisher Chi-square & 148.373 & $0.000^{* * *}$ & ADF-Fisher Chi-square & -4.871 \\
\hline
\end{tabular}

$* /[* *] /[* * *]$ denotes si9gnificance level at $10 \% / 5 \%$ and $1 \%$ respectively 
After the panel data unit root test the authors carried out a poolability test between the pooled and the fixed effect models, to estimate which panel data model was appropriate in this paper. The random effect model was seen to be less effective for poolability testing. This is because Baltagi (2008:17) said random effect model is appropriate if draws are to be made randomly from a large population were $\mathrm{N}$ is significantly large. In this paper $N=3$ (3 supermarkets) $<T$ $=2.066$ (2yearsand 8 months), Thus, an insufficient size to permit the random effect model testing. To decide between the pooled and the fixed effect model, the $\mathrm{F}$ test and Chi-square test were performed. In order to correct for heteroscedasticity the white cross section was used. After performing the relevant poolability test, the fixed effect model which assumes cross section heterogeneity was considered. A conducted test for individual fixed effects for sampled cross sections (supermarkets) rejected that cross sections are homogenous, Implying that the behavioural relationship between price and market share is different for each individual supermarket. Thus, the fixed effect model confirmed to be the most robust and representative model specification. Results for the poolability test are depicted in table 4.2.

Table 4.2. Results for fixed effects

\begin{tabular}{|c|c|c|c|c|}
\hline Input/output & FixedeffectEstimates & Q-Statistic & $p$ value & Conclusion \\
\hline \multirow{2}{*}{ P1\&Q1 } & F-Statistics & 2031.774 & $0.000 * * *$ & \multirow[t]{2}{*}{$H_{0}$ was rejected } \\
\hline & Chi-square & 365.799 & $0.000 * * *$ & \\
\hline P1\&Q2 & F-Statistics & 937.920 & $0.000 * * *$ & $H_{0}$ was rejected \\
\hline \multirow{2}{*}{ P3\&Q3 } & F-Statistics & 357176.083 & $0.000 * * *$ & \multirow[t]{2}{*}{$H_{0}$ was rejected } \\
\hline & Chi-square & 859.917 & $0.000 * * *$ & \\
\hline \multirow{2}{*}{ P4\&Q4 } & F-Statistics & 181.957 & $0.000 * * *$ & \multirow[t]{2}{*}{$H_{0}$ was rejected } \\
\hline & Chi-square & 153.649 & $0.000 * * *$ & \\
\hline \multirow{2}{*}{ P5\&Q5 } & F-Statistics & 31.845 & $0.000 * * *$ & \multirow[t]{2}{*}{$H_{0}$ was rejected } \\
\hline & Chi-square & 50.503 & $0.000 * * *$ & \\
\hline \multirow{2}{*}{ P6\&Q6 } & F-Statistics & 19987.053 & $0.000 * * *$ & \multirow[t]{2}{*}{$H_{0}$ was rejected } \\
\hline & Chi-square & 583.343 & $0.000 * * *$ & \\
\hline \multirow{2}{*}{ P7\&Q7 } & F-Statistics & 105436.831 & $0.000 * * *$ & \multirow{2}{*}{$H_{0}$ was rejected } \\
\hline & Chi-square & 742.816 & $0.000 * * *$ & \\
\hline \multirow{2}{*}{ P8\&Q8 } & F-Statistics & 5858.161 & $0.000 * * *$ & \multirow{2}{*}{$H_{0}$ was rejected } \\
\hline & Chi-square & 466.058 & $0.000 * * *$ & \\
\hline P9\&Q9 & F-Statistics & 19491.564 & $0.000 * * *$ & $H_{0}$ was rejected \\
\hline \multirow{2}{*}{ P10\&Q10 } & F-Statistics & 3264.471 & $0.000 * * *$ & \multirow[t]{2}{*}{$H_{0}$ was rejected } \\
\hline & Chi-square & 410.516 & $0.000 * * *$ & \\
\hline \multirow{2}{*}{ P11\&Q11 } & F-Statistics & 1933.121 & $0.000 * * *$ & \multirow[t]{2}{*}{$H_{0}$ was rejected } \\
\hline & Chi-square & 361.129 & $0.000 * * *$ & \\
\hline
\end{tabular}

$* /[* *] /[* * *]$ denotes significance level at $10 \% / 5 \%$ and $1 \%$ respectively

Table 4.3. Model estimation results

\begin{tabular}{|c|c|c|c|c|}
\hline Input/output & Supermarket & Coefficient & $p$ values & R square \\
\hline \multirow{3}{*}{ P1\& Q1 } & Pick n' Pay & -22.390 & $0.000 * * *$ & \multirow{3}{*}{0.980} \\
\hline & Spar & -15.824 & $0.000 * * *$ & \\
\hline & Shoprite & -27.194 & $0.000 * * *$ & \\
\hline \multirow[t]{3}{*}{ P2 \& Q2 } & Spar & -32.208 & $0.046^{* *}$ & \multirow[t]{3}{*}{0.954} \\
\hline & Shoprite & -43.587 & $0.000 * * *$ & \\
\hline & Pick n' Pay & -117.118 & $0.000 * * *$ & \\
\hline \multirow[t]{3}{*}{ P3 \& Q3 } & Spar & -48.438 & $0.000 * * *$ & \multirow[t]{3}{*}{0.999} \\
\hline & Shoprite & -72.176 & $0.000 * * *$ & \\
\hline & Pick n' Pay & -34.208 & $0.000 * * *$ & \\
\hline \multirow[t]{3}{*}{ P4 \& Q4 } & Spar & -29.776 & $0.000 * * *$ & \multirow{3}{*}{0.841} \\
\hline & Shoprite & -18.746 & $0.000 * * *$ & \\
\hline & Pick n' Pay & -2.237 & $0.000 * * *$ & \\
\hline \multirow[t]{3}{*}{ P5 \& Q5 } & Spar & -2.089 & $0.003 * * *$ & \multirow[t]{3}{*}{0.823} \\
\hline & Shoprite & -4.112 & $0.000 * * *$ & \\
\hline & Pick n' Pay & -68.204 & $0.000 * * *$ & \\
\hline \multirow[t]{2}{*}{ P6 \& Q6 } & Spar & -43.509 & $0.000 * * *$ & \multirow[t]{2}{*}{0.998} \\
\hline & Pick n' Pay & -32.075 & $0.002 * * *$ & \\
\hline \multirow[t]{3}{*}{ P7 \& Q7 } & Spar & -44.993 & $0.003 * * *$ & \multirow[t]{3}{*}{0.999} \\
\hline & Shoprite & -65.857 & $0.000 * * *$ & \\
\hline & Pick n' Pay & -46.967 & $0.000 * * *$ & \\
\hline \multirow[t]{3}{*}{ P8 \& Q8 } & Spar & -26.796 & $0.000 * * *$ & \multirow[t]{3}{*}{0.995} \\
\hline & Shoprite & -17.739 & $0.000 * * *$ & \\
\hline & Pick n' Pay & -56.434 & $0.000 * * *$ & \\
\hline \multirow[t]{2}{*}{ P9 \& Q9 } & Spar & -21.872 & $0.000 * * *$ & \multirow[t]{2}{*}{0.998} \\
\hline & Shoprite & -50.339 & $0.000 * * *$ & \\
\hline
\end{tabular}




\begin{tabular}{lllll}
\hline Input/output & Supermarket & Coefficient & pvalues & R square \\
\hline & Pick n' Pay & -79.515 & $0.000^{* * *}$ & 0.086 \\
& Spar & -47.507 & $0.017^{*}$ & \\
& Shoprite & -85.588 & $0.000^{* * *}$ & \\
P11 \& Q11 & Pick n' Pay & -9.261 & $0.051^{* *}$ & 0.992 \\
& Spar & -16.004 & $0.000^{* * *}$ & $0.000^{* * *}$ \\
\hline
\end{tabular}

$* /[* *] /[* * *]$ denotes significance level at $10 \% / 5 \%$ and $1 \%$ respectively

Poolability test reflected that, the null hypothesis that the data must be estimated by pooled model is rejected against the alternative that it must not. According to Gujarati (2004:642), the fixed effect try to indicate the differences in special features like managerial style, organisational philosophy or the target market of an organisation. After the poolability test was done, the model estimation was performed on all 11 studied items. The model estimation had to establish the level of trueness of the problem statement with regards to the model specification and the selected panel data model. Despite the fact that the fixed effect model was the considered model in this paper, model estimation was conducted for both fixed and pooled model. The aim was to perfectly establish that the fixed effect model was the most appropriate model to be considered. The R squares between the pooled and the fixed effect models were compared. $\mathrm{R}$ squares indicates the least results of 0.8228 and a high value of 0.9999 for fixed effect. The pooled model had a least result of -0.004280 and a maximum of 0.691226 . Thus, the fixed effect model confirmed to be the most robust and representative model specification. Results showed that all independent variables (price) are all significant in explaining the dependent variables (market share) for all 11 tested items. Table 4.3 presents the model estimation results for fixed effects.

To further elaborate on the interpretation of table 4.6 if considering input and output variable (P1 \& Q1) for instance; the coefficient indicates that a R1 increase in the price for white star maize meal $5 \mathrm{~kg}$ by any of the sampled supermarket against competitors, sales will decrease by 22 , 15 and 27 units for Pick $\mathrm{n}$ Pay, Spar and Shoprite respectively. Likewise a R1 decrease in the price for Whit star maize meal $5 \mathrm{~kg}$ by any of the sampled supermarkets against competitors will increase sales by 22, 15 and 27 units for Pick n Pay, Spar and Shoprite respectively. The $p$ values of Pick n Pay (0.0006), Spar (0.0009) and Shoprite (0.0002) indicates the level of significance in which the independent variable (price) explains the dependent variable (market share) for sampled supermarkets for White star maize meal 5 $\mathrm{kg}$ is $0 \%$ for Pick n Pay, Spar and Shoprite respectively. The adjusted $\mathrm{R}$ square of 0.980400 indicates that $98 \%$ of the variation in market share for sampled supermarkets for White star maize meal $5 \mathrm{~kg}$ is been explain by price. Meaning only $2 \%$ of the variation in market share for sampled supermarkets is been explain by other determinants such as quality and advertising. Same explanations hold for all other tested items in table 4.3 .

Lastly, the diagnostic tests were conducted. Brooks (2009: 43) mentioned that the diagnostic tests are required in a panel analyses because they show that estimation techniques like the (OLS) linear regression may have ignored a series of undesirable elements. Brook also said the diagnostic test also try to confirm if coefficient estimates from regressions are justifiable or fairly conducted. In this paper the diagnostic tests were conducted to ensure reliability of results from linear regression. The diagnostic tests conducted in this study were the normality, serial correlation and heteroscedasticity. Results from each of this test are presented in table 4.4.

Table 4.4. Diagnostic tests

\begin{tabular}{lll}
\hline Test & Measurement & Conclusion \\
\hline $\begin{array}{l}\text { Normality test } \\
H_{0}: \text { all } \mathrm{i} \text { is normally distributed }\end{array}$ & Jarque-Bera & Errors were normally distributed. Thus regressions failed to reject $H_{0}$ \\
$H_{1}:$ not all $\mathrm{i}$ is normally distributed & & \\
$\begin{array}{l}\text { Serial correlation test } \\
H_{0}: \rho=0\end{array}$ & $\begin{array}{l}\text { Correllogram Q-statistics test } \\
H_{1}: \rho \neq 0 .\end{array}$ & Authors concluded that no serial correlation was present in the models \\
Heteroscedasticity & White's cross section & The white cross-section was used to correct the problem of heteroscedasticity. \\
$H_{0}: \sigma_{\mathrm{i}}^{2}=\sigma$ & & \\
$H_{1}:$ not equal for all $\mathrm{i}$ & & \\
\hline
\end{tabular}

Lastly forecasting was conducted. Forecasting was done in this paper to show how accurate were regression models in predicting the value of quantity demanded. Forecasting results is represented in appendix 1 . The blue and the red line reflect the actual versus the fitted values. The first, second and third relationships in the figures represent Pick n Pay, Spar and Shoprite supermarkets respectively. With regards to the outcome from forecasting, the model of this study was concluded accurate since the predicted or forecasted values mimic the actual values. Thus, the model can be used for forecasting future quantity demand for a specified price for a product.

\section{Conclusions}

The problem identified in this study was the lack of awareness among retailers in the Ngaka Modiri Molema district on the role of price in market share gain or loss. Thus, the main aim of this study was to increase the level of awareness of the influence of price on market share gain or 
loss among Ngaka Modiri Molema retailers. After conducting an empirical research through a panel data analysis on the three largest supermarkets in the Ngaka Modiri Molema district, results reflect that price plays a major role in market share gain or loss among retailers in the Ngaka Modiri Molema district in general. The researcher recommends that retailers should dedicate more attention on pricing in order to increase their market share

All three sampled supermarkets in this paper had a positive outcome to this conclusion. Regression outcomes indicated that consumers' measures price transparency among retailers in order to make a purchase decision. Results showed that a supermarket that has the most moderate pricing for a certain product had the highest market share of that product. It was seen that an increase in price will affect consumers' behaviour negatively and consequently lost in market share. Likewise a decrease in price of a product will affect consumers' behaviour positively and consequently market share gain. Findings also indicated that market share domination is very important for supermarkets in the Ngaka Modiri Molema district. Extensive price wars were initiated by supermarkets for products in which they had a dominant market of share

However, critiques can argue the effectiveness of the role of price in influencing market share if other determinants (error term) were not taken in to consideration in the model specification. Hence, the used of the panel data analysis technique made available a solution to such criticisms. This is because regression results from the model estimations gave an indication of all changes of the dependent variable influence by other determinants over the studied period. Results indicated that changes made by other determinants were not up to $20 \%$ for each tested items among all sample supermarkets. This is highly supported by the $\mathrm{R}$ square results were the least adjusted $\mathrm{R}$ square is $82 \%$.

Thus, it was necessary that the authors should develop a pricing decision support system (framework) that will assist Ngaka Modiri Molema fast consumer goods retailers in developing appropriate pricing decision. The frame work that was developed in this paper was adopted from Kehagias et al. (2009). Kehagias et al. came up with a framework which suggested that pricing decision for any product category is to be guided by a specific objective. Thus retailers should guide pricing decision with the objective of increasing market share. The mentioned framework was modified to fit in to the context our paper.

This model assumed that pricing dimensions and pricing determinants are strongly connected. Hence, it is important that Ngaka Modiri Molema fast consumer goods retailers should simultaneously consider both pricing dimensions and pricing determinant in developing pricing decisions. The model indicates some internal and external factors that Ngaka Modiri Molema retailers should consider when making pricing decision. The model further suggested that a pricing decision for any product category in the fast consumer goods industry will involve either an increase or decrease in price. However, whatever pricing decision a retailer select, retailers objective should be towards market share gain.

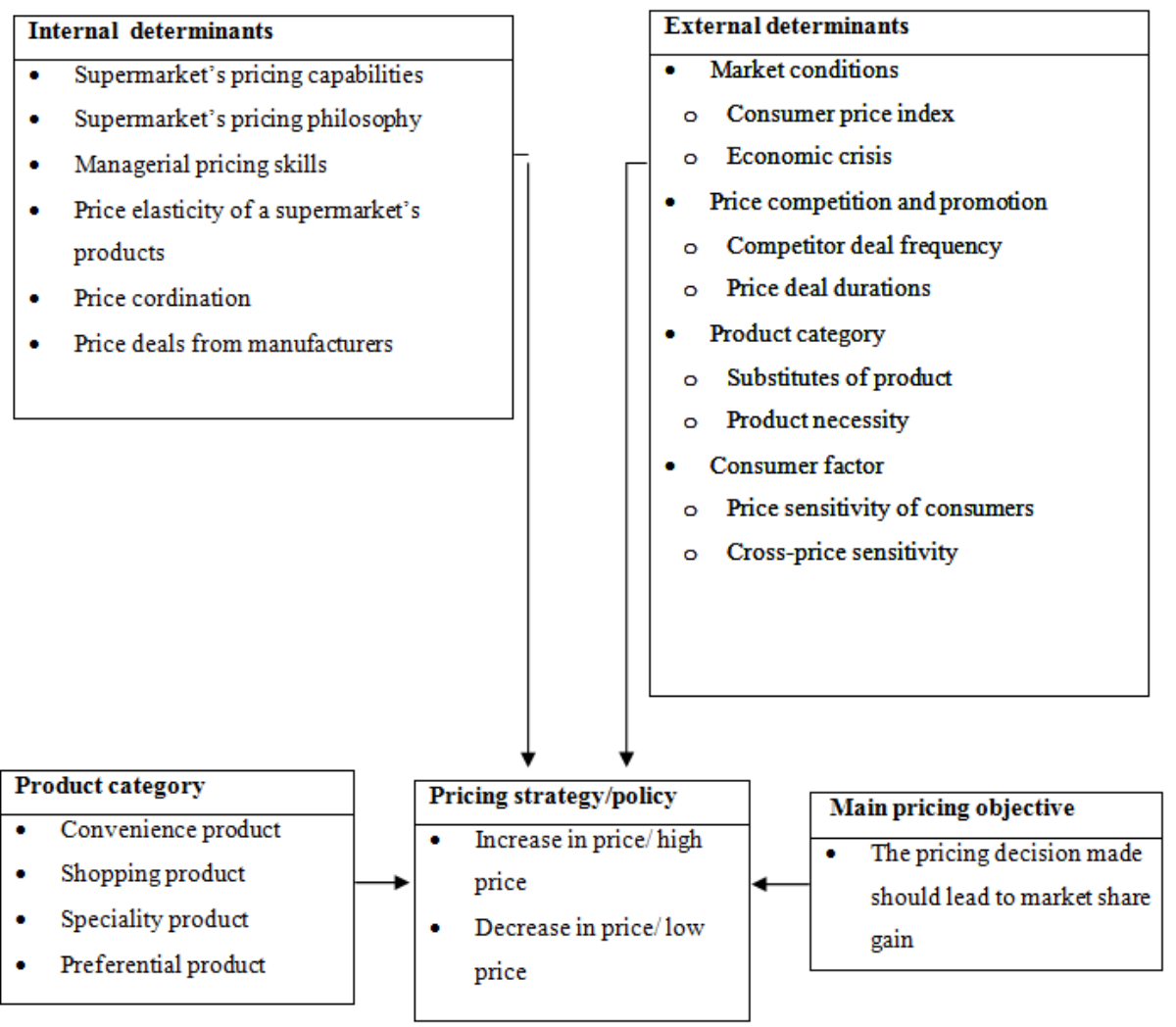

Figure 5.1.Pricing decision support system for Ngaka Modiri Molema retailers 


\subsection{Advantages of the Proposed Model}

It will enable fast consumer goods retailers in the Ngaka Modiri Molema district to select the most appropriate pricing strategies and policies for their target market

It fits accurately in the Ngaka Modiri Molema fast consumer goods retail sector. Its implementation is straight and forward and easy to understand.

\subsection{Drawbacks of the Proposed Model}

The might be issues of limited information with respect to new products and actions of competitors. However it is important to have a contingency plan for handling such shortcomings

The application of the model may only permit decision making in the fast consumer goods industry.

Most fast consumer goods retailers in the Nkaga Modiri Molema district may lack analytical abilities in handling most dynamics in the model. However skills can be improve through training programs

It is hoped that the findings of this paper will encourage retailers to take pricing seriously and will also implement the propose pricing decision support system in making more appropriate and effective pricing decisions in order to improve their market shares.

\section{Aknowledegement}

Special thanks to Mr. Andrew Maredza of the School of management Sciences, North University, Mafikeng Campus for his continuous support and encouragement throughout this paper

My endless gratitude to the sampled supermarkets who participated in this study. Special thanks to their regional and branch managers for making available reliable data for this paper.

\section{Authors Information}

Mr. Benedict Ateba has just completed his masters in the school of management science at the North-West University of South Africa. His current research focus is on developing decision support systems in the South Africa retail sector within the heavy weight, lightweight and banking retail sectors. Private bag X2046, Mmabatho, 2735, South Africa. Mobile:+27(0)736902154.Email:atebabenedict@yahoo.com( correspondingauthor)

Professor Hein Prinsloo is a senior lecturer at the NorthWest University Business School. He supervised my masters studies in the area of pricing and market share. Email:Hein.prinsloo@nwu.co.za.

\section{Appendix 1}

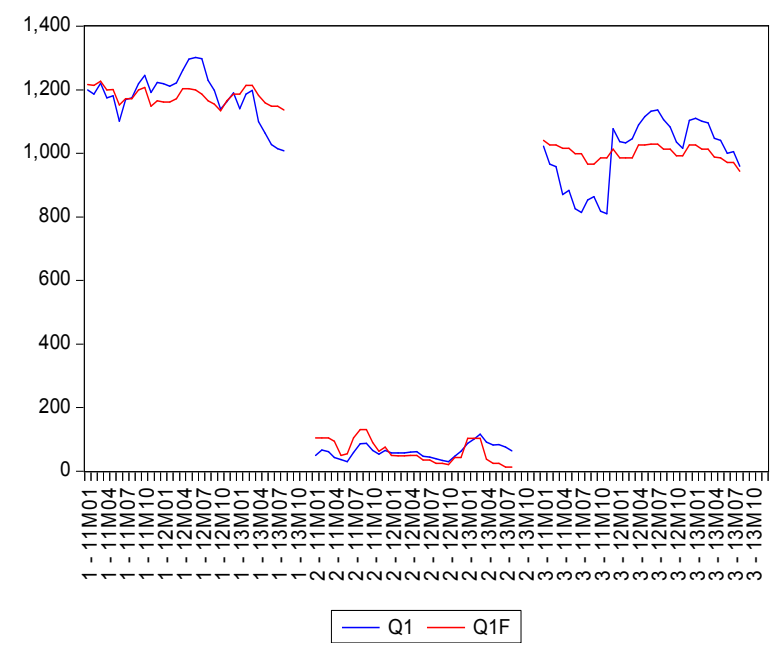

Figure 1. Forecasting results for White star maize meal

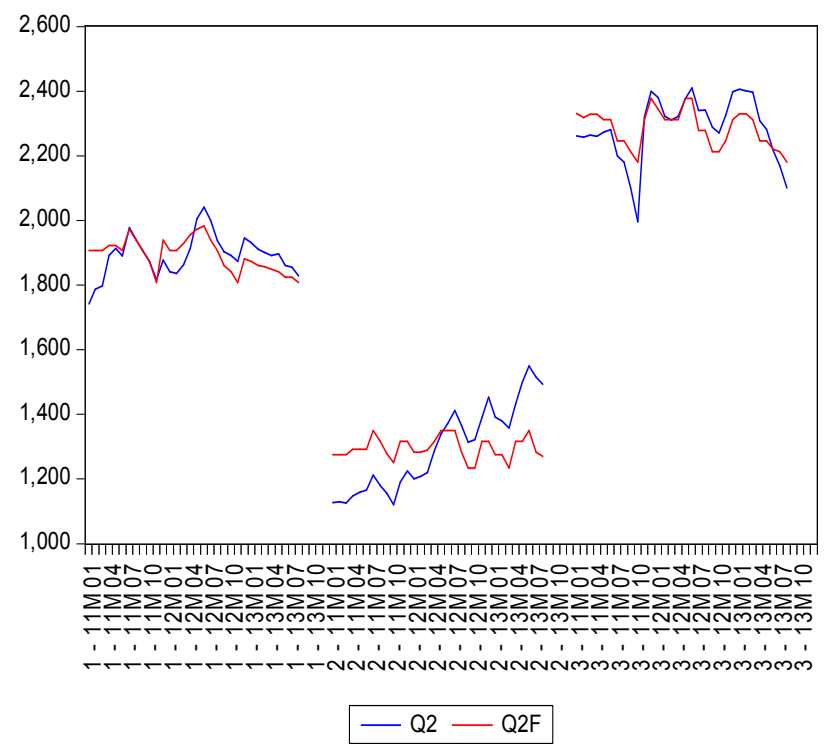

Figure 2. Forecasting results for Tastic rice

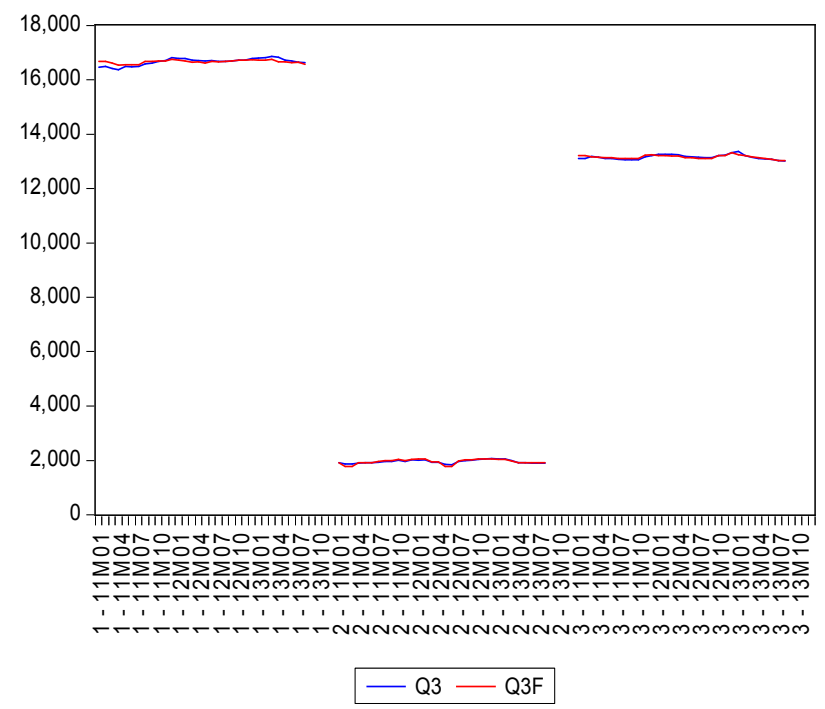

Figure 3. Forecasting results for coke 2 litres 


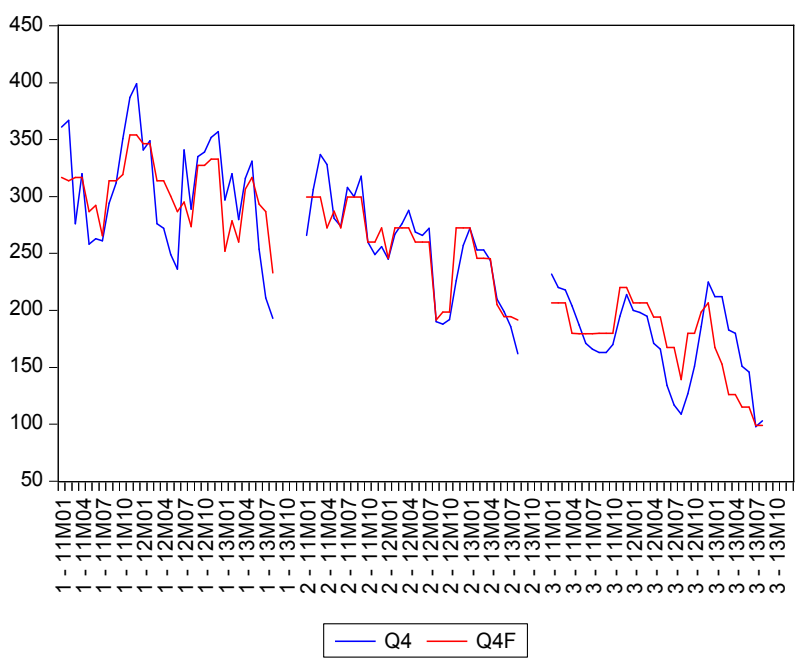

Figure 4. Forecasting results for potato chips

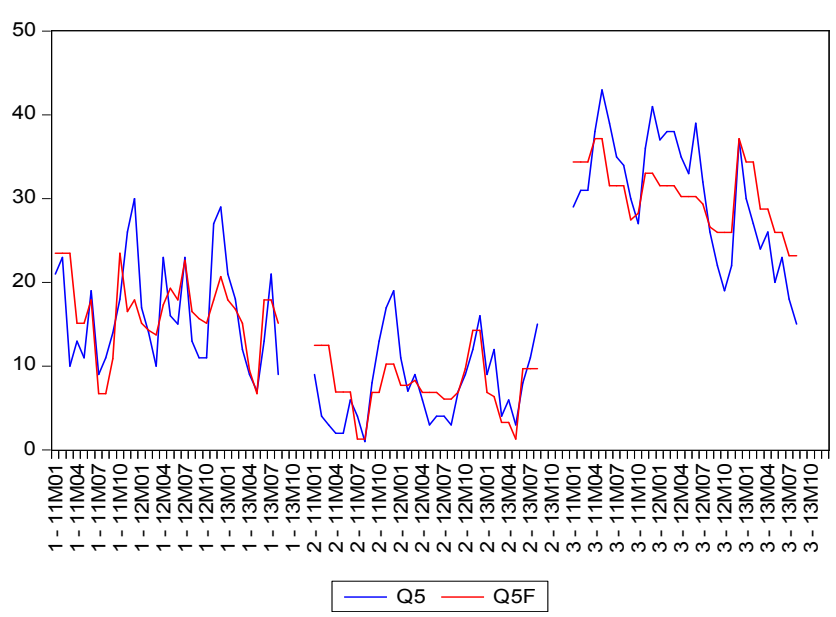

Figure 5. Forecasting results for axe deodorant spray

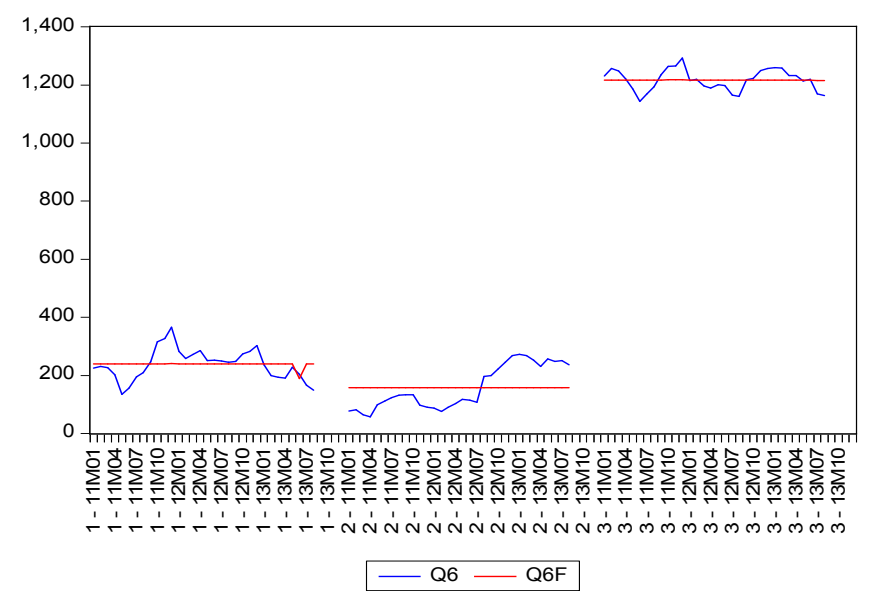

Figure 6. Forecastasting results for sasko bread

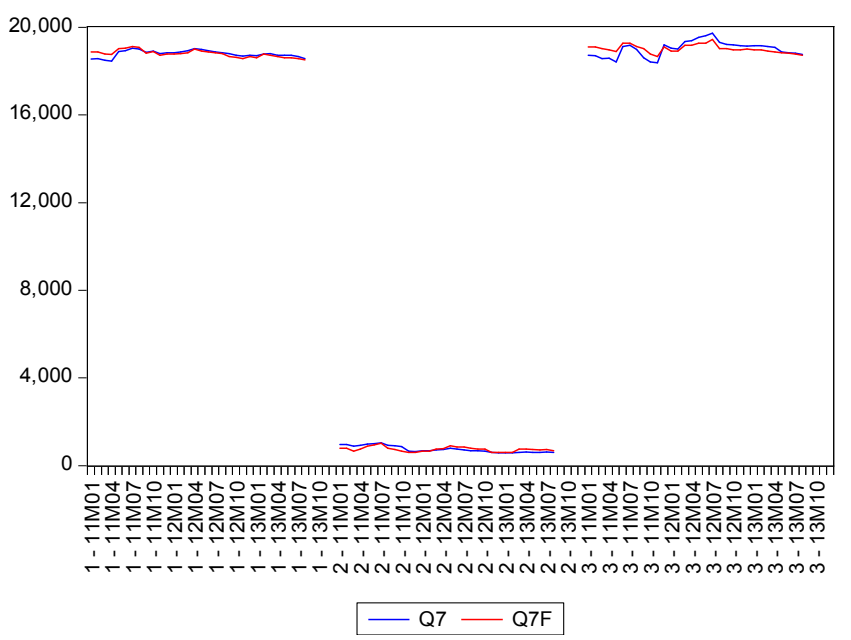

Figure 7. Forecasting results for Chicken braai cuts

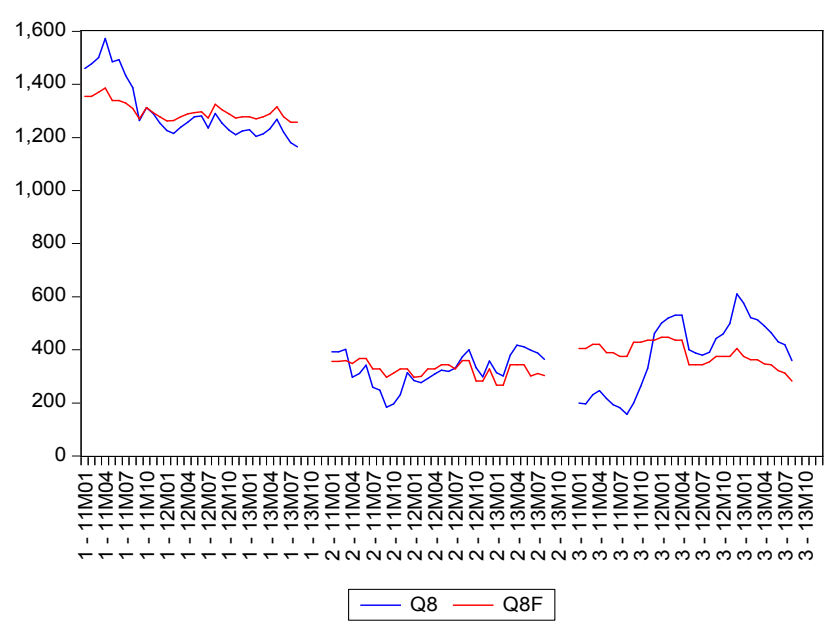

Figure 8. Forecasting results for Golden delicious apple
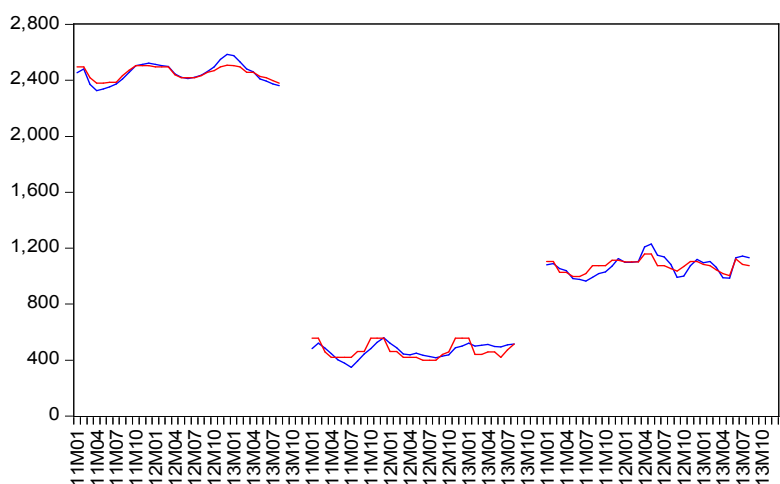

-

- Q9-Q9F

Figure 9. Forecasting results for Nutriday yogurt 


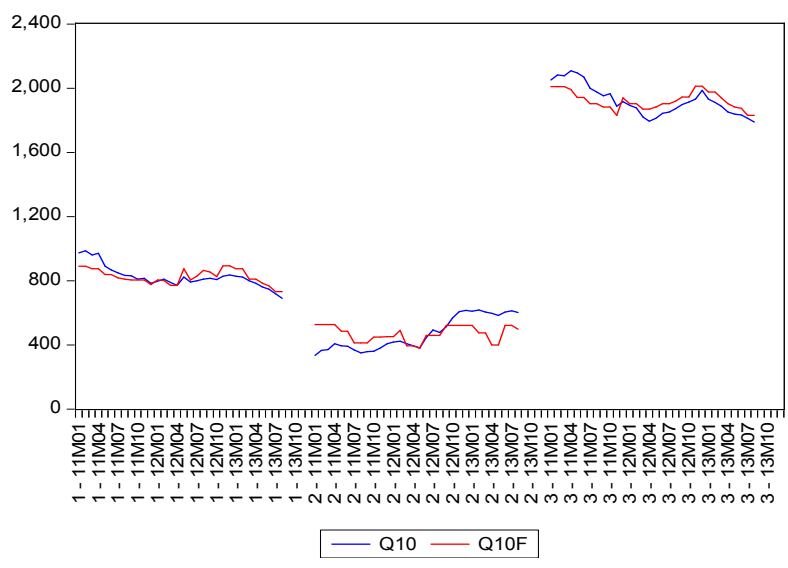

Figure 10. Forecasting result for Colgate tooth paste

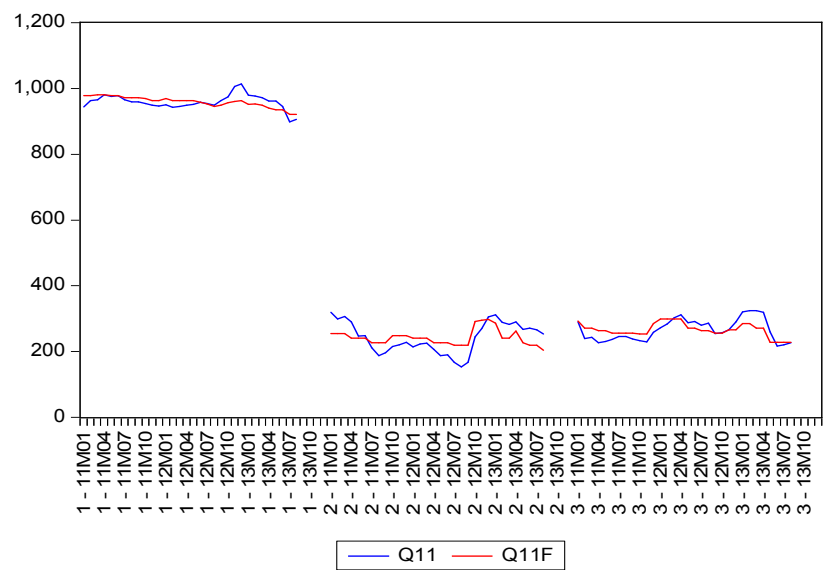

Figure 11. Forecasting results for Styvensen cigarette

\section{Appendix 2}

Table 1. Data used in analysing price change for the sampled Pick n Pay supermarket for (P1 to P11); from 2011 January to 2013August

\begin{tabular}{|c|c|c|c|c|c|c|c|c|c|c|c|}
\hline & & & & Pick n & price d & & & & & & \\
\hline 2011 & P1 & P2 & P3 & P4 & P5 & P6 & P7 & P8 & P9 & P10 & P11 \\
\hline JAN & 27.79 & 19.99 & 12.99 & 9.89 & 19.99 & 9.29 & 32.99 & 11.99 & 9.99 & 6.79 & 20.99 \\
\hline FEB & 27.99 & 19.99 & 12.99 & 9.99 & 19.99 & 9.29 & 32.99 & 11.99 & 9.99 & 6.79 & 20.99 \\
\hline MAR & 26.99 & 19.99 & 13.99 & 9.89 & 19.99 & 9.89 & 34.99 & 10.99 & 11.99 & 6.99 & 20.79 \\
\hline APR & 28.99 & 19.49 & 14.99 & 9.89 & 22.99 & 9.89 & 35.17 & 10 & 12.99 & 6.99 & 20.79 \\
\hline MAY & 28.89 & 19.49 & 14.79 & 10.99 & 22.99 & 10.49 & 29.99 & 12.99 & 12.99 & 7.49 & 21 \\
\hline JUN & 32.49 & 19.99 & 14.79 & 10.79 & 21.99 & 10.29 & 29.49 & 12.99 & 12.79 & 7.49 & 21 \\
\hline JUL & 30.99 & 17.99 & 14.69 & 11.79 & 25.99 & 9.99 & 27.99 & 13.65 & 12.79 & 7.79 & 21.39 \\
\hline AUG & 30.99 & 18.99 & 12.99 & 9.99 & 25.99 & 9.99 & 28.99 & 14.99 & 11.59 & 7.89 & 21.39 \\
\hline SEP & 28.99 & 19.99 & 12.99 & 9.99 & 24.49 & 9.49 & 33.99 & 17.49 & 10.59 & 7.99 & 21.39 \\
\hline OCT & 28.49 & 20.99 & 12.79 & 9.79 & 19.99 & 9 & 32.49 & 14.74 & 9.79 & 7.99 & 21.59 \\
\hline $\mathrm{NOV}$ & 32.79 & 22.99 & 12.79 & 8.49 & 22.49 & 8.92 & 35.99 & 15.99 & 9.79 & 7.99 & 21.99 \\
\hline DEC & 31.49 & 18.99 & 11.99 & 8.49 & 21.99 & 8.49 & 34.89 & 16.99 & 9.79 & 8.39 & 21.99 \\
\hline 2012 & P1 & P2 & P3 & P4 & P5 & P6 & P7 & P8 & P9 & P10 & P11 \\
\hline JAN & 31.79 & 19.99 & 12.49 & 8.79 & 22.99 & 9.49 & 34.89 & 17.99 & 9.99 & 7.99 & 21.59 \\
\hline FEB & 31.79 & 19.99 & 12.79 & 8.79 & 23.29 & 9.99 & 34.49 & 17.95 & 9.99 & 8 & 21.99 \\
\hline MAR & 30.99 & 19.29 & 13.49 & 9.99 & 23.49 & 9.59 & 33.49 & 16.99 & 9.99 & 8.47 & 21.99 \\
\hline APR & 28.79 & 18.49 & 13.29 & 9.99 & 22.19 & 9.35 & 30.29 & 16.29 & 11.49 & 8.47 & 21.99 \\
\hline MAY & 28.79 & 17.99 & 13.79 & 10.49 & 21.49 & 9.99 & 31.99 & 15.99 & 11.99 & 6.99 & 22 \\
\hline JUN & 28.99 & 17.69 & 12.99 & 10.99 & 21.99 & 9.99 & 32.79 & 15.79 & 11.99 & 7.99 & 22.39 \\
\hline JUL & 29.99 & 18.99 & 13.26 & 10.69 & 20.29 & 10 & 33.49 & 17.29 & 11.99 & 7.65 & 22.75 \\
\hline AUG & 31.49 & 19.99 & 12.99 & 11.49 & 22.49 & 10 & 34.29 & 13.89 & 11.59 & 7.15 & 23.29 \\
\hline SEP & 32.29 & 21.39 & 12.79 & 9.49 & 22.79 & 9.99 & 36.99 & 15.29 & 11 & 7.29 & 22.99 \\
\hline OCT & 33.79 & 21.99 & 12.49 & 9.49 & 22.99 & 9.59 & 37.89 & 16.29 & 10.69 & 7.69 & 22.49 \\
\hline NOV & 31.49 & 22.99 & 12.49 & 9.29 & 21.99 & 9.29 & 39 & 17.29 & 9.99 & 6.75 & 22.19 \\
\hline DEC & 29.99 & 20.75 & 12.19 & 9.29 & 20.99 & 8.99 & 37 & 16.99 & 9.69 & 6.75 & 21.99 \\
\hline 2013 & P1 & P2 & P3 & P4 & P5 & P6 & P7 & P8 & P9 & P10 & P11 \\
\hline JAN & 29.99 & 20.99 & 12.49 & 12.29 & 21.99 & 10.29 & 38 & 16.99 & 9.79 & 6.99 & 22.79 \\
\hline FEB & 27.99 & 21.39 & 12.29 & 11.29 & 22.39 & 10.99 & 34.89 & 17.49 & 9.99 & 6.99 & 22.75 \\
\hline MAR & 27.99 & 21.49 & 12 & 11.99 & 22.99 & 10.99 & 35.99 & 17 & 10.99 & 7.89 & 23 \\
\hline APR & 30.29 & 21.75 & 13.29 & 10.26 & 24.99 & 9.99 & 37.29 & 16.29 & 10.99 & 7.89 & 23.59 \\
\hline MAY & 31.99 & 21.99 & 13.29 & 9.89 & 25.99 & 9.49 & 37.99 & 14.51 & 11.79 & 8.29 & 24 \\
\hline JUN & 32.75 & 22.49 & 13.65 & 10.75 & 21.99 & 99.99 & 38 & 16.99 & 11.99 & 8.49 & 24 \\
\hline JUL & 32.75 & 22.49 & 13.39 & 10.99 & 21.99 & 10.69 & 38.99 & 18.29 & 12.49 & 8.99 & 24.99 \\
\hline AUG & 33.59 & 22.99 & 14.45 & 12.99 & 22.99 & 10.99 & 39.99 & 18.29 & 12.99 & 8.99 & 24.99 \\
\hline SEP & - & - & - & - & - & - & - & - & - & - & - \\
\hline OCT & - & - & - & - & - & - & - & - & - & - & - \\
\hline NOV & - & - & - & - & - & - & - & - & - & - & - \\
\hline
\end{tabular}

DEC 
Table 2. Data used in analysing market share variation with regards to price change for the sampled Pick $n$ Pay supermarket for (Q1 to Q11); from 2011 January to 2013 August.

\begin{tabular}{|c|c|c|c|c|c|c|c|c|c|c|c|}
\hline & & & & Pick & sales & & & & & & \\
\hline 2011 & Q1 & Q2 & Q3 & Q4 & Q5 & Q6 & Q7 & Q8 & Q9 & Q10 & Q11 \\
\hline JAN & 1200 & 1742 & 16457 & 361 & 21 & 225 & 18543 & 1459 & 2453 & 974 & 944 \\
\hline FEB & 1186 & 1787 & 16490 & 367 & 23 & 231 & 18571 & 1477 & 2481 & 986 & 964 \\
\hline MAR & 1220 & 1797 & 16411 & 276 & 10 & 227 & 18489 & 1500 & 2370 & 960 & 966 \\
\hline APR & 1175 & 1892 & 16364 & 320 & 13 & 203 & 18456 & 1573 & 2328 & 969 & 981 \\
\hline MAY & 1181 & 1913 & 16495 & 258 & 11 & 135 & 18900 & 1485 & 2338 & 889 & 976 \\
\hline JUN & 1101 & 1890 & 16472 & 263 & 19 & 157 & 18935 & 1492 & 2352 & 866 & 978 \\
\hline JUL & 1169 & 1978 & 16492 & 261 & 9 & 195 & 19042 & 1433 & 2374 & 849 & 966 \\
\hline AUG & 1174 & 1940 & 16586 & 294 & 11 & 209 & 19006 & 1388 & 2410 & 832 & 960 \\
\hline SEP & 1219 & 1906 & 16622 & 312 & 14 & 247 & 18847 & 1264 & 2456 & 829 & 960 \\
\hline OCT & 1245 & 1873 & 16670 & 351 & 18 & 315 & 18913 & 1312 & 2505 & 811 & 954 \\
\hline $\mathrm{NOV}$ & 1191 & 1817 & 16705 & 387 & 26 & 327 & 18797 & 1290 & 2513 & 814 & 950 \\
\hline DEC & 1223 & 1877 & 16811 & 399 & 30 & 366 & 18834 & 1255 & 2523 & 784 & 947 \\
\hline 2012 & Q1 & Q2 & Q3 & Q4 & Q5 & Q6 & Q7 & Q8 & Q9 & Q10 & Q11 \\
\hline JAN & 1219 & 1841 & 16778 & 341 & 17 & 283 & 18842 & 1226 & 2514 & 795 & 951 \\
\hline FEB & 1212 & 1836 & 16778 & 349 & 14 & 258 & 18878 & 1215 & 2506 & 810 & 943 \\
\hline MAR & 1221 & 1863 & 16725 & 276 & 10 & 273 & 18933 & 1239 & 2500 & 789 & 946 \\
\hline APR & 1261 & 1913 & 16700 & 272 & 23 & 286 & 19022 & 1257 & 2447 & 772 & 949 \\
\hline MAY & 1296 & 2005 & 16687 & 249 & 16 & 251 & 18981 & 1278 & 2421 & 823 & 952 \\
\hline JUN & 1302 & 2041 & 16699 & 236 & 15 & 252 & 18923 & 1281 & 2412 & 791 & 958 \\
\hline JUL & 1298 & 2000 & 16673 & 341 & 23 & 250 & 18866 & 1236 & 2420 & 799 & 954 \\
\hline AUG & 1230 & 1938 & 16685 & 289 & 13 & 246 & 18833 & 1291 & 2436 & 811 & 949 \\
\hline SEP & 1199 & 1903 & 16690 & 335 & 11 & 248 & 18790 & 1254 & 2464 & 816 & 964 \\
\hline OCT & 1139 & 1891 & 16713 & 339 & 11 & 274 & 18715 & 1227 & 2498 & 807 & 975 \\
\hline NOV & 1162 & 1874 & 16722 & 352 & 27 & 282 & 18677 & 1210 & 2550 & 827 & 1006 \\
\hline DEC & 1190 & 1946 & 16780 & 357 & 29 & 302 & 18724 & 1225 & 2585 & 835 & 1014 \\
\hline 2013 & Q1 & Q2 & Q3 & Q4 & Q5 & Q6 & Q7 & Q8 & Q9 & Q10 & Q11 \\
\hline JAN & 1141 & 1932 & 16804 & 297 & 21 & 237 & 18689 & 1229 & 2576 & 828 & 980 \\
\hline FEB & 1187 & 1911 & 16816 & 320 & 18 & 199 & 18772 & 1204 & 2530 & 822 & 977 \\
\hline MAR & 1198 & 1900 & 16871 & 280 & 12 & 193 & 18795 & 1213 & 2483 & 800 & 973 \\
\hline APR & 1100 & 1892 & 16819 & 316 & 9 & 190 & 18726 & 1233 & 2462 & 785 & 962 \\
\hline MAY & 1063 & 1897 & 16720 & 331 & 7 & 228 & 18712 & 1269 & 2409 & 761 & 962 \\
\hline JUN & 1027 & 1860 & 16687 & 254 & 13 & 204 & 18709 & 1220 & 2395 & 749 & 945 \\
\hline JUL & 1015 & 1856 & 16650 & 211 & 21 & 167 & 18660 & 1181 & 2374 & 718 & 899 \\
\hline AUG & 1009 & 1829 & 16631 & 193 & 9 & 150 & 18575 & 1165 & 2363 & 690 & 907 \\
\hline SEP & - & - & - & - & - & - & - & - & - & - & - \\
\hline OCT & - & - & - & - & - & - & - & - & - & - & - \\
\hline NOV & - & - & - & - & - & - & - & - & - & - & - \\
\hline
\end{tabular}

DEC

Table 3. Data used in analysing price change for the sampled Spar supermarket for (P1 to P11); from 2011 January to 2013August.

\begin{tabular}{|c|c|c|c|c|c|c|c|c|c|c|c|}
\hline & & & & & Spar & price & data & & & & \\
\hline 2011 & P1 & P2 & P3 & P4 & P5 & P6 & P7 & P8 & P9 & P10 & P11 \\
\hline JAN & 28.92 & 20.25 & 14.99 & 8.99 & 22 & 9.85 & 34.29 & 14.19 & 9.99 & 6.92 & 25 \\
\hline FEB & 28.92 & 20.25 & 16.99 & 8.99 & 22 & 9.85 & 34.49 & 14.19 & 9.99 & 6.92 & 25 \\
\hline MAR & 28.92 & 20.25 & 16.99 & 8.99 & 22 & 10.29 & 37 & 13.99 & 12.49 & 6.92 & 25 \\
\hline APR & 29.65 & 19.75 & 14.99 & 9.99 & 23.99 & 10.29 & 34.99 & 14.63 & 13.49 & 6.92 & 25.99 \\
\hline MAY & 32.95 & 19.75 & 14.99 & 9.45 & 23.99 & 9.89 & 32.19 & 13.41 & 13.49 & 7.51 & 25.99 \\
\hline JUN & 32.49 & 19.75 & 14.99 & 9.99 & 23.99 & 9.89 & 31.29 & 13.41 & 13.49 & 7.51 & 25.99 \\
\hline JUL & 28.9 & 17.99 & 14.21 & 8.99 & 25.99 & 9.85 & 29.99 & 15.99 & 13.49 & 8.52 & 27 \\
\hline AUG & 27 & 18.99 & 13.79 & 8.99 & 25.99 & 9.85 & 34.49 & 15.99 & 12.45 & 8.52 & 27 \\
\hline SEP & 27 & 20.15 & 13.79 & 8.99 & 24 & 9.85 & 35.39 & 17.99 & 12.45 & 8.52 & 27 \\
\hline OCT & 29.99 & 20.99 & 13.29 & 10.45 & 24 & 9.85 & 37.17 & 16.99 & 9.99 & 8 & 25.45 \\
\hline NOV & 32 & 18.99 & 13.79 & 10.45 & 22.79 & 10 & 37.99 & 15.99 & 9.99 & 8 & 25.45 \\
\hline DEC & 31 & 18.99 & 13.17 & 9.99 & 22.79 & 10 & 37.99 & 15.99 & 9.99 & 7.99 & 25.45 \\
\hline 2012 & P1 & P2 & P3 & P4 & P5 & P6 & P7 & P8 & P9 & P10 & P11 \\
\hline JAN & 32.92 & 19.99 & 13 & 10.99 & 23.71 & 10.49 & 36.99 & 17.99 & 12.45 & 7.99 & 25.99 \\
\hline FEB & 32.99 & 19.99 & 13 & 9.99 & 23.71 & 10.49 & 36.99 & 17.79 & 12.45 & 7.45 & 25.99 \\
\hline MAR & 32.99 & 19.79 & 14.45 & 9.99 & 23.49 & 9.85 & 34.99 & 15.99 & 13.49 & 8.79 & 25.99 \\
\hline APR & 32.95 & 18.99 & 14.45 & 9.99 & 24 & 9.85 & 34.79 & 15.99 & 13.49 & 8.79 & 27 \\
\hline MAY & 32.95 & 17.99 & 16.95 & 10.45 & 24 & 9.85 & 31.99 & 14.95 & 13.49 & 8.99 & 27 \\
\hline JUN & 33.99 & 17.99 & 16.95 & 10.45 & 24 & 9.99 & 32.99 & 14.95 & 13.99 & 7.89 & 27 \\
\hline JUL & 33.99 & 17.99 & 13.99 & 10.45 & 24.29 & 11.69 & 32.99 & 15.99 & 13.99 & 7.89 & 27.49 \\
\hline
\end{tabular}




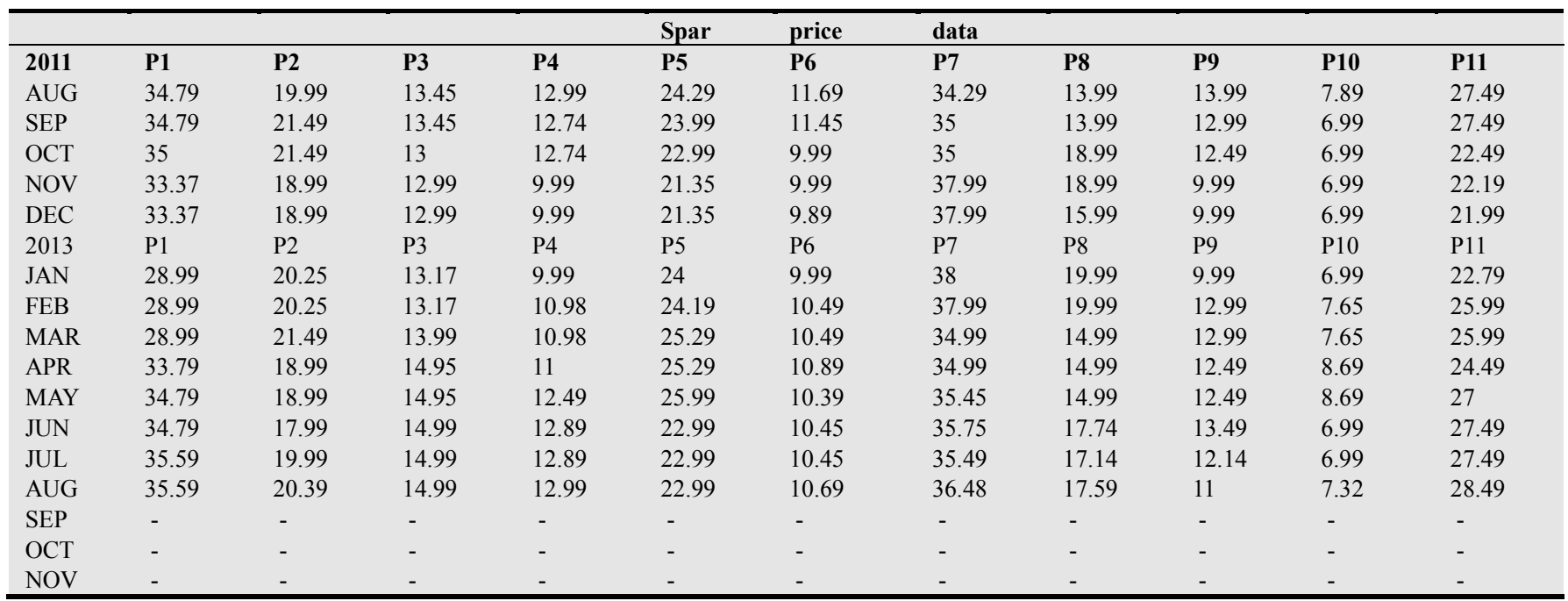

DEC

Table 4. Data used in analysing market share variation with regards to price change for the sampled Spar supermarket for (Q1 to Q11); from 2011 January to 2013 August.

\begin{tabular}{|c|c|c|c|c|c|c|c|c|c|c|c|}
\hline & & & & Spar & 3 & data & & & & & \\
\hline 2011 & Q1 & Q2 & Q3 & Q4 & Q5 & Q6 & Q7 & Q8 & Q9 & Q10 & Q11 \\
\hline JAN & 50 & 1127 & 1912 & 266 & 9 & 78 & 970 & 393 & 482 & 336 & 320 \\
\hline FEB & 66 & 1130 & 1864 & 306 & 4 & 82 & 967 & 392 & 520 & 366 & 299 \\
\hline MAR & 61 & 1125 & 1862 & 337 & 3 & 65 & 896 & 402 & 485 & 370 & 307 \\
\hline APR & 43 & 1147 & 1900 & 328 & 2 & 57 & 934 & 297 & 447 & 408 & 290 \\
\hline MAY & 36 & 1159 & 1909 & 281 & 2 & 100 & 982 & 312 & 403 & 394 & 247 \\
\hline JUN & 30 & 1166 & 1917 & 274 & 6 & 112 & 1008 & 343 & 378 & 392 & 249 \\
\hline JUL & 59 & 1211 & 1928 & 308 & 4 & 123 & 1045 & 260 & 349 & 367 & 212 \\
\hline AUG & 86 & 1180 & 1959 & 300 & 1 & 133 & 931 & 248 & 391 & 351 & 187 \\
\hline SEP & 88 & 1156 & 1966 & 318 & 8 & 134 & 903 & 185 & 444 & 358 & 196 \\
\hline OCT & 65 & 1120 & 2003 & 260 & 13 & 134 & 864 & 196 & 482 & 362 & 216 \\
\hline NOV & 53 & 1190 & 1960 & 249 & 17 & 97 & 653 & 231 & 526 & 380 & 221 \\
\hline DEC & 65 & 1225 & 2011 & 256 & 19 & 91 & 641 & 315 & 560 & 406 & 228 \\
\hline 2012 & Q1 & Q2 & Q3 & Q4 & Q5 & Q6 & Q7 & Q8 & Q9 & Q10 & Q11 \\
\hline JAN & 58 & 1200 & 2009 & 245 & 11 & 88 & 674 & 285 & 520 & 418 & 215 \\
\hline FEB & 57 & 1208 & 2019 & 267 & 7 & 76 & 678 & 276 & 489 & 423 & 224 \\
\hline MAR & 57 & 1219 & 1936 & 276 & 9 & 91 & 715 & 292 & 444 & 409 & 226 \\
\hline APR & 60 & 1288 & 1930 & 288 & 6 & 104 & 731 & 309 & 437 & 393 & 207 \\
\hline MAY & 61 & 1340 & 1845 & 269 & 3 & 118 & 790 & 324 & 451 & 381 & 187 \\
\hline JUN & 47 & 1372 & 1841 & 266 & 4 & 114 & 753 & 319 & 435 & 445 & 191 \\
\hline JUL & 44 & 1411 & 1953 & 272 & 4 & 108 & 721 & 331 & 426 & 493 & 167 \\
\hline AUG & 39 & 1366 & 2000 & 190 & 3 & 197 & 685 & 374 & 416 & 477 & 153 \\
\hline SEP & 34 & 1314 & 2004 & 188 & 7 & 200 & 679 & 401 & 430 & 513 & 168 \\
\hline OCT & 30 & 1322 & 2045 & 192 & 9 & 222 & 650 & 333 & 437 & 567 & 245 \\
\hline NOV & 46 & 1390 & 2049 & 226 & 12 & 246 & 598 & 299 & 488 & 606 & 271 \\
\hline DEC & 63 & 1453 & 2066 & 257 & 16 & 268 & 582 & 358 & 502 & 614 & 306 \\
\hline 2012 & Q1 & Q2 & Q3 & Q4 & Q5 & Q6 & Q7 & Q8 & Q9 & Q10 & Q11 \\
\hline JAN & 88 & 1391 & 2052 & 272 & 9 & 272 & 587 & 314 & 522 & 610 & 312 \\
\hline FEB & 101 & 1380 & 2048 & 253 & 12 & 268 & 579 & 302 & 501 & 617 & 289 \\
\hline MAR & 116 & 1358 & 1990 & 253 & 4 & 253 & 612 & 380 & 506 & 605 & 283 \\
\hline APR & 91 & 1432 & 1922 & 244 & 6 & 231 & 625 & 418 & 511 & 596 & 291 \\
\hline MAY & 82 & 1500 & 1914 & 210 & 3 & 256 & 611 & 412 & 498 & 584 & 267 \\
\hline JUN & 84 & 1550 & 1899 & 199 & 8 & 248 & 607 & 399 & 493 & 605 & 272 \\
\hline JUL & 76 & 1515 & 1899 & 186 & 11 & 251 & 618 & 388 & 509 & 612 & 266 \\
\hline AUG & 64 & 1493 & 1894 & 162 & 15 & 237 & 598 & 364 & 516 & 601 & 254 \\
\hline SEP & - & - & - & - & - & - & - & - & - & - & - \\
\hline OCT & - & - & - & - & - & - & - & - & - & - & - \\
\hline NOV & - & - & - & - & - & - & - & - & - & - & - \\
\hline DEC & - & - & - & - & - & - & - & - & - & - & - \\
\hline
\end{tabular}


Table 5. Data used in analysing price change for the sampled Shoprite supermarket for (P1 to P11); from 2011 January to 2013 August.

\begin{tabular}{|c|c|c|c|c|c|c|c|c|c|c|c|}
\hline & & & & Shoprite & price & data & & & & & \\
\hline 2011 & P1 & $\mathbf{P 2}$ & P3 & P4 & P5 & P6 & P7 & P8 & P9 & P10 & P11 \\
\hline JAN & 28 & 19.39 & 12.49 & 8.99 & 18.99 & 9.45 & 33.29 & 11.99 & 9.17 & 6.49 & 25.45 \\
\hline FEB & 29 & 19.79 & 12.49 & 8.99 & 18.99 & 9.45 & 33.29 & 11.99 & 9.17 & 6.49 & 26.99 \\
\hline MAR & 29 & 19.49 & 12.94 & 8.99 & 18.99 & 9.45 & 34.99 & 10.99 & 11.21 & 6.49 & 26.99 \\
\hline APR & 29.79 & 19.49 & 13.17 & 9.99 & 17.99 & 9.99 & 35.99 & 10.99 & 11.21 & 6.75 & 27.45 \\
\hline May & 29.79 & 19.99 & 13.49 & 10 & 17.99 & 10.99 & 37.29 & 12.99 & 12 & 7.45 & 27.45 \\
\hline JUN & 30.99 & 19.99 & 13.49 & 10 & 19.99 & 11 & 29.99 & 12.99 & 12 & 7.45 & 27.99 \\
\hline AUG & 33.47 & 21.99 & 13.99 & 9.99 & 19.99 & 9.99 & 32.99 & 13.99 & 10 & 8 & 27.99 \\
\hline SEP & 33.47 & 22.99 & 13.99 & 9.99 & 21.45 & 9.49 & 34.99 & 10.45 & 10 & 8.29 & 27.99 \\
\hline OCT & 32 & 23.99 & 13.99 & 9.99 & 21.17 & 9 & 39.99 & 10.45 & 9.99 & 8.29 & 28.21 \\
\hline NOV & 32 & 19.99 & 12.17 & 8.49 & 19.45 & 8.99 & 41.99 & 9.99 & 8.99 & 8.99 & 28.21 \\
\hline DEC & 29.99 & 17.99 & 11.99 & 8.49 & 19.45 & 8.45 & 33.29 & 9.99 & 8.99 & 7.49 & 25.99 \\
\hline 2012 & $\mathrm{P} 1$ & $\mathrm{P} 2$ & P3 & P4 & P5 & P6 & P7 & P8 & P9 & P10 & P11 \\
\hline JAN & 31.99 & 18.99 & 12.45 & 8.99 & 19.99 & 9.45 & 36.89 & 9.24 & 9.29 & 7.99 & 25 \\
\hline APR & 28.99 & 19.99 & 12.75 & 9.45 & 20.45 & 9.99 & 31.99 & 10 & 7.89 & 8.47 & 24.99 \\
\hline May & 28.99 & 17.99 & 13.49 & 9.45 & 20.45 & 10.29 & 29.99 & 15.99 & 7.89 & 8.29 & 26.99 \\
\hline JUN & 28.79 & 17.99 & 13.49 & 10.45 & 20.45 & 10.29 & 29.99 & 15.99 & 10 & 7.99 & 26.99 \\
\hline JUL & 28.79 & 20.99 & 13.99 & 10.45 & 20.79 & 11 & 26.45 & 15.99 & 10 & 7.99 & 27.49 \\
\hline AUG & 29.99 & 20.99 & 13.99 & 11.49 & 21.75 & 11 & 34.99 & 15.29 & 10.49 & 7.79 & 27.49 \\
\hline SEP & 29.99 & 22.99 & 13.99 & 9.99 & 21.99 & 9.99 & 34.99 & 13.99 & 11 & 7.39 & 28 \\
\hline OCT & 31.45 & 22.99 & 12.29 & 9.99 & 21.99 & 9.99 & 35.99 & 13.99 & 10.17 & 7.39 & 28 \\
\hline NOV & 31.45 & 21.99 & 12.29 & 9.29 & 21.99 & 9.45 & 35.99 & 13.99 & 9.19 & 6.45 & 27.29 \\
\hline DEC & 28.99 & 19.99 & 11 & 8.99 & 17.99 & 9.45 & 35.29 & 11.99 & 9.19 & 6.45 & 27.29 \\
\hline 2013 & $\mathrm{P} 1$ & $\mathrm{P} 2$ & P3 & P4 & P5 & P6 & P7 & P8 & P9 & P10 & P11 \\
\hline JAN & 28.99 & 19.45 & 11.99 & 10.45 & 18.99 & 9.39 & 35.99 & 13.99 & 9.75 & 6.99 & 26 \\
\hline FEB & 29.99 & 19.45 & 12.49 & 10.99 & 18.99 & 9.39 & 35.99 & 14.75 & 9.99 & 6.99 & 26 \\
\hline MAR & 29.99 & 19.99 & 12.99 & 11.99 & 20.99 & 10.29 & 36.99 & 14.75 & 10.75 & 7.49 & 26.99 \\
\hline APR & 31.75 & 21.99 & 13.49 & 11.99 & 20.99 & 10.29 & 37.99 & 15.75 & 11.45 & 7.99 & 26.99 \\
\hline May & 31.99 & 21.99 & 13.99 & 12.39 & 21.99 & 10.99 & 38.79 & 15.99 & 11.79 & 8.29 & 29.99 \\
\hline AUG & 34.99 & 23.99 & 14.99 & 12.99 & 22.99 & 11.99 & 40.99 & 19.99 & 9.99 & 8.99 & 29.99 \\
\hline SEP & - & - & - & - & - & - & - & - & - & - & - \\
\hline OCT & - & - & - & - & - & - & - & - & - & - & - \\
\hline $\mathrm{NOV}$ & - & - & - & - & - & - & - & - & - & - & - \\
\hline DEC & - & - & - & - & - & - & - & - & - & - & - \\
\hline
\end{tabular}

Table 6. Data used in analysing market share variation with regards to price change for the sampled Shoprite supermarket for (Q1 to Q11); from 2011 January to 2013 August.

\begin{tabular}{|c|c|c|c|c|c|c|c|c|c|c|c|}
\hline & & & & Shoprite & sales & data & & & & & \\
\hline 2011 & Q1 & Q2 & Q3 & Q4 & Q5 & Q6 & Q7 & Q8 & Q9 & Q10 & Q11 \\
\hline JAN & 1023 & 2262 & 13100 & 232 & 29 & 1231 & 18714 & 200 & 1080 & 2051 & 290 \\
\hline FEB & 966 & 2258 & 13111 & 220 & 31 & 1257 & 18689 & 197 & 1091 & 2081 & 240 \\
\hline MAR & 958 & 2264 & 13177 & 218 & 31 & 1249 & 18560 & 231 & 1053 & 2076 & 243 \\
\hline APR & 871 & 2260 & 13150 & 204 & 38 & 1221 & 18593 & 247 & 1039 & 2109 & 227 \\
\hline MAY & 883 & 2273 & 13112 & 187 & 43 & 1186 & 18420 & 217 & 982 & 2094 & 231 \\
\hline JUN & 826 & 2281 & 13109 & 171 & 39 & 1143 & 19113 & 194 & 977 & 2069 & 237 \\
\hline AUG & 853 & 2180 & 13058 & 163 & 34 & 1193 & 18985 & 157 & 993 & 1975 & 246 \\
\hline SEP & 864 & 2100 & 13053 & 163 & 30 & 1236 & 18600 & 200 & 1017 & 1953 & 239 \\
\hline OCT & 817 & 1996 & 13056 & 170 & 27 & 1264 & 18412 & 263 & 1031 & 1966 & 233 \\
\hline NOV & 810 & 2321 & 13174 & 195 & 36 & 1266 & 18376 & 332 & 1072 & 1888 & 229 \\
\hline DEC & 1077 & 2400 & 13208 & 214 & 41 & 1292 & 19200 & 461 & 1126 & 1915 & 259 \\
\hline 2012 & Q1 & Q2 & Q3 & Q4 & Q5 & Q6 & Q7 & Q8 & Q9 & Q10 & Q11 \\
\hline JAN & 1037 & 2381 & 13259 & 200 & 37 & 1215 & 19032 & 501 & 1099 & 1891 & 273 \\
\hline MAR & 1046 & 2311 & 13248 & 195 & 38 & 1196 & 19347 & 530 & 1103 & 1820 & 303 \\
\hline APR & 1089 & 2323 & 13244 & 171 & 35 & 1190 & 19388 & 531 & 1208 & 1794 & 312 \\
\hline MAY & 1116 & 2376 & 13182 & 166 & 33 & 1201 & 19530 & 400 & 1230 & 1811 & 288 \\
\hline JUN & 1133 & 2411 & 13175 & 134 & 39 & 1198 & 19611 & 388 & 1150 & 1843 & 292 \\
\hline JUL & 1137 & 2340 & 13146 & 117 & 32 & 1165 & 19719 & 380 & 1137 & 1851 & 281 \\
\hline AUG & 1107 & 2342 & 13138 & 109 & 26 & 1161 & 19309 & 391 & 1084 & 1872 & 287 \\
\hline
\end{tabular}




\begin{tabular}{|c|c|c|c|c|c|c|c|c|c|c|c|}
\hline & & & & Shoprite & sales & data & & & & & \\
\hline 2011 & Q1 & Q2 & Q3 & Q4 & Q5 & Q6 & Q7 & Q8 & Q9 & Q10 & Q11 \\
\hline SEP & 1083 & 2289 & 13133 & 127 & 22 & 1218 & 19225 & 443 & 993 & 1897 & 255 \\
\hline OCT & 1036 & 2271 & 13219 & 151 & 19 & 1222 & 19187 & 460 & 999 & 1913 & 257 \\
\hline $\mathrm{NOV}$ & 1016 & 2325 & 13227 & 186 & 22 & 1250 & 19158 & 500 & 1075 & 1930 & 266 \\
\hline DEC & 1103 & 2399 & 13311 & 225 & 37 & 1256 & 19145 & 611 & 1120 & 1986 & 291 \\
\hline 2013 & Q1 & Q2 & Q3 & Q4 & Q5 & Q6 & Q7 & Q8 & Q9 & Q10 & Q11 \\
\hline JAN & 1111 & 2406 & 13364 & 212 & 30 & 1259 & 19153 & 576 & 1097 & 1930 & 321 \\
\hline MAR & 1096 & 2397 & 13155 & 183 & 24 & 1233 & 19115 & 514 & 1062 & 1888 & 325 \\
\hline APR & 1047 & 2309 & 13103 & 180 & 26 & 1232 & 19075 & 490 & 990 & 1851 & 319 \\
\hline MAY & 1040 & 2283 & 13080 & 151 & 20 & 1214 & 18866 & 465 & 984 & 1837 & 260 \\
\hline JUN & 1000 & 2217 & 13063 & 146 & 23 & 1219 & 18841 & 431 & 1133 & 1831 & 217 \\
\hline JUL & 1006 & 2169 & 13025 & 98 & 18 & 1169 & 18810 & 419 & 1145 & 1812 & 221 \\
\hline AUG & 960 & 2100 & 13011 & 103 & 15 & 1164 & 18757 & 360 & 1132 & 1789 & 227 \\
\hline SEP & - & - & - & - & - & - & - & - & - & - & - \\
\hline $\mathrm{NOV}$ & - & - & - & - & - & - & - & - & - & - & - \\
\hline DEC & - & - & - & - & - & - & - & - & - & - & - \\
\hline
\end{tabular}

\section{References}

[1] Balcombe K. (2009-2010). The nature and determinants of volatility in agriculture prices: An empirical study from 19622008. Commodity market review.

[2] Baltagi B. H. (2008). Econometric analysis of panel data. (4th ed), Chicester, John Wiley \& Sons Ltd.

[3] Blyth J. (2006).Principles and practice of marketing. London, Thompson Learning.

[4] Claessen S., Kose M. A \& Terrones M. E. What happens during recessions, crunches and bust? Economic Policy. (2009) $(60-62)$ pp.653-700. http://www.econstor.eu/bitstream/10419/45452/1/638354102. pdf.

[5] De-Jagar N. (2004). The living standard measure as a market segmentation tool for selected retailers. Dissertation in masters of commerce at Northwest university Potchestroom campus.

[6] Derby, R. (2013). Recovering market share a big task for Pick n' Pay. www.bdlive.co.za/opinion/columnists/203/04/24/recovering market share-a-big-task-for-pick-n-pay.

[7] Dirkie U. (2012).Success stories. Section One. Invest Northwest Annual repport 2010/2011.

[8] Dutta S., Zbaracki M.J. \& Bergen M. Pricing process as a capability: A resource-based perspective. Strategic management journal. (2003) (24) pp.615-630. http://onlinelibrary.wiley.com/doi/10.1002/smj.323/pdf

[9] Egan J. (2007). Marketing communication.1sted,London, Thomson.

[10] Esclana N. S., Diginis C., Plessis R., Machado R., Mpinganjira M., McIntee H., Kloppers R. S. \& Theron D. (2012) Introduction to marketing. 4thed, Cape Town, JUTA \& Company Ltd

[11] Furrier, O., Alexander M. T. \&Sudharshan, D. The impact of resource strategy correspondence on marketing performancefinancial performance - tradeoffs. Journal of strategic marketing (2007) (15) pp.161-183. http://gatton.uky.edu/falculty/sudharshan/puplications/The $\% 2$ 0impact $\% 200 \mathrm{f} \% 20$ resources-

strategyonMarketingPerformanceFinancialPerformancetradeof f.pdf.

[12] Gujarati, D.N. (2004). Basic Econometrics. 4th ed. New York. McGraw-Hall.

[13] Guruprakash R. \&Sohn T. H. (2008). A dissertation submitted to the engineering systems division in the partial fulfilment for the degree masters engineering in logistics. Massachusetts Institute of Technology

[14] Hinterhuber A. \&Liozu S. (2012).Is time to rethink your pricing strategy.MIT Sloan management review (summer 2012 release)

[15] Indounas K. \&Avlonitis G. J. Pricing objectives and their antecedents in the services sector. Journal of service marketing. (2009) 20(3) pp.342-374. http://www.emeraldinsight.com/doi/pdfplus/10.1108/0956423 0910964426

[16] Kehagias J. \& Skourtis E. and Aikaterini V. Pricing strategy and practice: Plaiting pricing in to product categories and corporate objectives. Journal of product \& brand management. (2009) 18(1), pp.67-76. http://www.emeraldinsight.com/doi/pdfplus/10.1108/1061042 0910933380

[17] Khan, S (2011). Marketing mix strategy adaptation: A retail organisation's response to global economic downturn. Masters dissertation in technology marketing. Cape Peninsula University of Technology.

[18] Lee, C., \& Griffith, D. A. The marketing strategy-performance relationship in an export-driven developing economy: A Korean illustration. International Marketing Review, (2004) 21(3), pp.321-334. http://www.emeraldinsight.com/doi/pdfplus/10.1108/0265133 0410539648

[19] Mariri T. \& Chipunza C. In-store shopping environment and impulse buying. African journal of marketing management. (2009) 1(4) pp.102-108. http://www.academicjournals.org/article/article1379493526_T endai\%2520 and 2520Crispen.pdf. 
[20] McGregor G.(2010). Shoprite vs Pick n' Pay: The showdown. www.fin24.com/companies/shoprite-vs-pick-n-pay-theshowdown-20100509.

[21] Moutinho L. \& Chien C. (2008). Problems in marketing: Applying key concepts and techniques. 2nded, London, SAGE Publications.

[22] Munusamy J \& Hoo W.C. Relationship between marketing mix strategy and consumer motive: An empirical study in major TESCO stores. Unitar E- journal. (2008) 4(2) pp.41-56. http://www.myjurnal.my/filebank/published_article/219441rel ationship_jayaraman.pdf.

[23] Palley T. I. (2004). From Keynesianism to Neoliberalism: Shifting paradigms in economics

[24] Plessis P. J. \& Rousseau G.G (2007).Buying behaviour. Understanding consumer psychology and marketing. 4thed, Cape Town, Oxford University press.

[25] Rapsomanikis G. \& Sarris A. (2009-2010). Introduction. Commodity market review. Food and agriculture organisation of the united nation.

[26] Roger B. M. (2003). An investigation into how marketers cope with an environment of high complexity and turbulence with special reference to the South African environment. Dissertation in doctor of philosophy at Rhodes University.

[27] Roviere J. (2009). Price concept in economics.http://www.helium.com/items/207879-the-conceptof-price-in-economics [15 February 2009].
[28] Scheer L.V. The South African cherry picking consumer's price knowledge and gender issues. Problems and perspectives in management (2010) 8(3) pp.193-199 http://businessperspectives.org/journals_free/ppm/2010/PPM EN_2010_03_cont_Scheers.pdf

[29] Shankar A. C. \& Chin K. K.(2011).A study of the relationship between marketing mix and customer retention for herbal coffee in Malaysia. 2nd international conference of business and economic research proceeding.

[30] Southern Africa Legal Information Institute (SAFLII) (2012). South Africa: Ngaka Modiri High Court in Mafikeng. http//www.saflii.org.za/cases/zanwite/2012[17 July, 2013, 10.40a.m].

[31] Statistics South Africa CPI Sources and Methods Manual (Stat S.A CPISMM) (2009). Release V.1 February. http: //www.statsssa.gov.za/cpi/documents/CPI-sources method.pdf

[32] Venter P. \&Rensburg M. J (2009). Strategic marketing: Theory and application for competitive advantage. 1sted, Cape Town, Oxford University press.

[33] White House Associates (2007).The South African agri-food market report. Prepared for high commission of Canadian trade.

[34] Wiid J. (2012). Fundamentals of Merchandising.1sted, Cape Town, Juta\& Company Ltd. 